University for Business and Technology in Kosovo

UBT Knowledge Center

Oct 28th, 2:00 PM - 3:30 PM

\title{
The verbs in Mandarin-Chinese, Albanian and English, seen from the perspective of the Grammatical Tense
}

\section{Florim Ajdini}

Tetovo State University, florim.ajdini@unite.edu.mk

Follow this and additional works at: https://knowledgecenter.ubt-uni.net/conference

Part of the Education Commons

\section{Recommended Citation}

Ajdini, Florim, "The verbs in Mandarin-Chinese, Albanian and English, seen from the perspective of the Grammatical Tense" (2017). UBT International Conference. 116.

https://knowledgecenter.ubt-uni.net/conference/2017/all-events/116

This Event is brought to you for free and open access by the Publication and Journals at UBT Knowledge Center. It has been accepted for inclusion in UBT International Conference by an authorized administrator of UBT Knowledge Center. For more information, please contact knowledge.center@ubt-uni.net. 


\title{
The verbs in Mandarin-Chinese, Albanian and English, seen from the perspective of the Grammatical Tense
}

\author{
Florim V. Ajdini \\ Tetova State University, Macedonia. \\ florim.ajdini@unite.edu.mk
}

\begin{abstract}
Different from English and Albanian, verbs in Chinese-Mandarin, do not conjugate across pronouns which perform the action. They have no inflectional nature and features in none of the grammatical tenses which are in the focus of this paper. The Chinese verbs never go through case and person! This phenomenon, in a way makes life easier for the non-native learner of Chinese, not having to remember all verb particles in order to create the time effect, to express an action. It makes easier for the learners of this 'mega language', spoken by more than 1.300.000.000 people, to learn it easily. Given this, the word order in Chinese sentences is, very crucial. This order is the only alternative, to show the foreign learner, the effect of the relationship between the subject and the verb. Furthermore, the word order, changes compared to the one in Albanian and English, especially in cases when we have to deal with actions asking questions of interrogative character, which in a way remain the same as the affirmative or declarative ones. This paper, through a detailed comparative analysis, aims to put in focus the so called irregularities in Chines -Mandarin, or 'Putonghua'= (普通話)”, as to how tenses, are expressed in this language, using also the Romanized pin-yin letters.
\end{abstract}

Keywords: verbs, case, tense, comparison, Albanian, English and Chinese

\section{Introduction}

A short historical rundown of the Mandarin Chinese Putonghua"(普通話”)

The Mandarin Chinese, known also as the Huayu (華語) language, and referred to as the old Chinese, as well as Guoyu (國語), or the official language of China or even more popular known as Putonghua (普通話), or the language of the Chinese people, is the only official language of the Chinese state, since 1982. On the other hand, in Taiwan, starting from earlier times, i.e. from the year 1932, the Mandarin is the official language of the state. The Chinese mandarin language is one of the four official languages in Singapore, and finally one of the eight official languages of the Organization of the United Nations (Chen.H.W.1998:112).

The fact that starting from the time when China was constituted as a nation state, back in 221 B.C. until the end of China's last imperial dynasty in 1912, this immense country, did not have a single national language. In these circumstances, the Chinese people across the vast country of China, spoke many different language variations as well as dialects that developed organically over the course of several millennia. Somewhere by the early years of the 20th Century, most Chinese people agreed that the state of China needed a common language, a language which will be equal and welcome and usable for everybody, all in order to facilitate national communication and at the end after some long time of educational activity across the country, the state will be able to have combated finally the widespread illiteracy. 


\section{Further developments}

In February 1913, the newly established Republic of China (中華民國) convened a “Commission on the Unification of Pronunciation" (讀音統一會) in Beijing in order to develop a phonetic system and national language for China. The Commission included linguists and educators from each province of China, Tibet, Mongolia, and from overseas Chinese communities. The Commission's first task was to create a simple, easy to learn, phonetic system to help people learn the common Chinese language. Many different phonetic systems were proposed and tried, including a fixed set of Chinese characters, newly created symbols, and the Roman alphabet. After years of extensive research and debate, the Commission adopted the Zhuyin alphabet as China's official alphabet in 1918, deeming it to be the most effective method of teaching Chinese pronunciation.

The Commission then turned to the task of standardizing the language that the new Zhuyin alphabet would represent. In 1920, the Commission published a Dictionary of National Pronunciation.

(國音字典) that adopted a modification of Beijing's phonology. Mandarin was not modeled after the actual speech of the majority of real early 20th century Beijing residents, but rather the way a hypothetical educated Beijing person would speak, as imagined by Mandarin's creators (Hu Z. L.1994:222). The difference in China between Mandarin and common Beijing pronunciation is analogous to the difference in England between Received Pronunciation and Cockney. In 1932 the Republic of China (中華民國) officially adopted the Commission's product, known as Guoyu or Mandarin, as the national language of China and the first definitive dictionary of the Mandarin language was published in that year. After 1949, the newly installed People's Republic of China (中華人民共和國) began to promote Mandarin in earnest beginning in about 1958. In 1955, they changed the Chinese name of Mandarin from Guoyu to Putonghua. Guoyu, Putongua, and Huayu are simply different names for the identical language.

\section{Development changes regarding the status, in modern times}

In 1982, the People's Republic of China (中華人民共和國) amended their constitution making Mandarin the official language of mainland China. The earlier 1932 law by the Republic of China (中華民國) making Mandarin China's official language, while effective today in Taiwan, has no current legal effect in mainland China. When Mandarin was first officially adopted in 1932, its proponents' goal was that in a century's time, all Chinese would be able to speak proper Mandarin. Today, 79 years later, approximately $70 \%$ of Chinese people speak Mandarin fluently

\section{The phenomenon of grammatical tenses and examples revealing the differences}

Western languages such as English have several ways to express tense. The most common are verb conjunctions which change the form of the verb depending on the time frame. For example, the English verb "eat" can be changed to "ate" for past actions and "eating" for current actions. Mandarin Chinese does not have any verb conjugations. All verbs have a single form. For example, the verb for "eat" is 吃 (chī), which can be used for the past, present, and future. 
Despite the lack of Mandarin verb conjugations, there are other ways to express timeframes in Mandarin Chinese.

\section{Stating the date, as a way to express the completion of an action}

The simplest way to clarify which tense you are speaking in is to directly state the time expression (like today, tomorrow, yesterday) as part of the sentence. In Chinese, this is usually at the beginning of the sentence, which is pretty much the same situation in Albanian as well as in English, except the fact that these two languages, differently from Mandarin Chinese, use verbs expression actions in the past, future as well as in other grammatical tenses, which is not the case in Chinese Mandarin. For example:

昨天我吃豬肉。

昨天我吃猪肉。

Zuótiān wǒ chī zhū ròu.Yesterday I ate beef.

Once the timeframe is established, it is understood and can be omitted from the rest of the conversation.

\section{How do we express a completed action in general}

The particle $了$ (le) is used to indicate that an action occurred in the past and has been completed. Like the time expression, it can be omitted once the timeframe has been established:

(昨天)我吃猪肉了。

(昨天)我吃猪肉了。

(Zuótiān) wǒ chī zhū ròu le.(Yesterday) I ate beef.

The particle $了$ (le) can also be used for the immediate future, so be careful of its usage and be sure to understand both functions.

\section{Completed actions in the past}

When we talk about something we have done something in the past, then this action can be described with the verb-suffix 過 / 过 (guò). For example, if you want to say that you have already seen the movie "Crouching Tiger, Hidden Dragon" (臥虎藏龍/卧虎藏龙 - wò hŭ cáng long), you can say:

\section{我已經看過卧虎藏龍。}

我已经看过卧虎藏龙。

Wǒ y̌̉jing kàn guò wò hŭ cáng long.

Unlike the particle 了 (le), the verb suffix guò (過 / 过) is used to talk about an unspecific past. If you want to say that you saw the movie "Crouching Tiger, Hidden Dragon" yesterday, you would say:

昨天我看卧虎藏龍了。

昨天我看卧虎藏龙了。

Zuótiān wǒ kàn wò hǔ cáng lóng le. 


\section{.Completed actions in the future}

As mentioned above, the particle 了 (le) can be used for the future as well as the past. When used with a time expression such as 明天 (míngtīan - tomorrow), the meaning is similar to the English perfective. Take for instance:

明天我就会去台北了。

明天我就会去台北了。

Mingtiān wǒ jiù huì qù Táiběi le. Tomorrow I will have gone to Taipei -Nesër do të kem shkuar në Taipei

The near future, or as we usually prefer to refer to as 'the future in the past', (e ardhmja në të kryerën), is expressed with the combination of the particles 要 (yào - to intend- do të, alb.); 就 (jiù - right away); or 快 (kuài - soon) with the particle 了 (le):

我要去台北了。

Wó yào qù Táiběi le.

I'm just going to Taipei.

\section{Further examples and theoretical comparison between the concerned tenses, between Chinese, Albanian and English}

\section{Examples:}

Declarative sentence:

他是老师。

He is a teacher= tā shì lăo shī.

Interrogative sentence:

他是老师吗?

Is he a teacher?

tā shì lăo shī ma?

Declarative sentence:

我身体很好。

I am healthy.

Interrogative sentence:

你身体好吗?

How is your health?

nǐ shēn tǐ hăo ma ?

- As mentioned earlier, verbs are not inflected in Chinese. There is no past tense, future tense, singular form and plural form in Chinese. As the example above, we have the verb 'drink', but there is no such thing as drinks, drunk, drank, am drinking, will drink, etc. in Chinese.

- He 'drink' coffee.

- I 'drink' coffee now.

- They drink coffee yesterday.

- Or the case in Albanian, which we from the gerammatical point of view refer to as “ zgjedhimi I foljeve", is not an action which can be compared to the chinese, nor the the case in English as foreign language.

- The examples illustrating this, would be as follows:

Unë pi kafe - Ne pijmë kafe

Ti pi kafe - Ju pini kafe

Ai/Ajo pi kafe-Ata/Ato pijnë kafe 
In English, this phenomenon would look like as follows: ( There is no verb declination, as there is in the languages such as Albanian, German, French, Italian and other Slavic Languages)

She 'go' England.

She 'go' England last year

I 'go' (have been to) England before.

Instead of conjugating a verb, adverbs (such as tomorrow, right now) and particles are used in Chinese to denote what English does with different verb tenses.

3.2. He will go to England tomorrow- Ai, nesër niset për në Angli.

tā míng tiān qù yīng guó 。

他明天去英国。

Subject Adverbs Verb Object

3.3. He GO to England last year-Vitin e kaluar, ai SHKON në Angli.

tā qù nián qù yīng guó 。

他去年去英国。

Subject Adverbs Verb Object

3.4. He has been to England before.

tā qù guò yīng guó 。

他去过英 国。

Subject Verb Particle Object

Personally, I think Chinese grammar is much simpler if compared to English. As to the Albanian Grammar, Chinese grammar cannot be compared in these regard. This for the fact that Chinese has insignificantly low level of inflectionally, which makes the new learners keen to learn it, as not having this complex word formation, makes easier for the learners to learn words and not form words by using affixes ( suffixes and prefixes). There is always a fixed and single form in each word, regardless of time, number, person and etc. of the subject. On the other hand, due to the lack of inflectional morphology, Chinese grammar is mainly concerned with how words are arranged to form meaningful sentences.

\section{Conclusions}

Mandarin Chinese tenses, similarities and differences compared to Albanian and English

It is often said that Mandarin Chinese does not have any tenses. If "tenses" mean verb conjugation, this is true, since verbs in Chinese have an unchangeable form, which at most of the times, is not the case in Albanian, where verbs get conjugated through cases, as well as in English, when they are added and's' in Simple present tense, and accordingly other suffixes (for past 
tenses of regular verbs) in English. However, as we can see in the above examples, there are many ways to express timeframes in Mandarin Chinese., and the most common one is adding time adverbs or time indicators, to the sentence we want to express an action, as to when did it happen. The main difference in terms of grammar between Mandarin Chinese and European languages is that once a timeframe has been established in Mandarin Chinese, there is no longer any need for precision. This means sentences are constructed in simple forms without verb endings or other qualifiers.

When talking to a native Mandarin Chinese speaker, Westerners, as well as Albanian native speakers, who speak English fluently, usually get confused with this lack of continuous precision, within the time frame context of the action the verb is expressing. But this confusion arises from the comparison between English and other Western languages, as well as Albanian as an IndoEuropean Language, and Mandarin Chinese. Western languages require subject/verb agreements, just like the case of Albanian, without which the language will be glaringly wrong. Compare this with Mandarin Chinese, in which a simple statement can be in any timeframe, or express a question, or be an answer. In other words, it is impossible to produce sentences involving past simple tense as well as compound past simple tense, such as Present perfect and Past perfect, without involving in the sentence, the date the year or the year season when something happened. As this is the only way, how Chinese, indicated the time when something happened.

In this regard, all those who learn Mandarin Chinese, including me, although bizarre, find this phenomenon very easy to implement in the structures they want to show action in on of the past tenses of Chinese Mandarin. Having learn it once, the learner, understands how to do this, and uses these tenses with ease.

\section{References}

1. Beck, Sigrid, Toshiko Oda, and Koji Sugisaki, 2004. Parametric variation in the semantics of comparison: Japanese vs. English. Journal of East Asian Linguistics, 13:289- 344.

2. Bhatt, Rajesh and Shoichi Takahashi, 2007. Direct comparisons: Resurrecting the direct analysis of phrasal comparatives. Paper presented at SALT 17. Chierchia, Gennaro, 1998. Reference to kinds across languages. Natural Language Semantics, 6:339-405.

3. Chen, H. W. (1998). Chinese-English translation basis. China: Shanghai Foreign Language Education Press.

4. Hu, Z. L. (1994). Textual cohesion and coherence. China: Shanghai Foreign Language Education Press.

5. Huang, G. W. (1988). Text analysis introduction. Changsha, China: Hunan Education Press.

6. Kaplan R B. (1996). Cultural thought patterns in intercultural education. Language Learning, (2), 112-118.

7. Erlewine, Michael, 2007. A New Syntax-Semantics for the Mandarin 'bi' Comparative. Master's thesis, University of Michigan. Fu, Yi-Chin, 1978. Comparative structures in English and Mandarin Chinese. Ph.D. thesis, University of Michigan.

8. Heim, Irene, 1985. Notes on comparatives and related matters. Ms., University of Texas at Austin.

9. Liu, C. D. (1999). Teaching textual linguistics. China: Shanghai Foreign Language Education Press. Xu, Y. L. (1992).

10. Comparative linguistics. China: Shanghai Foreign Language Education Press 